\title{
Municipal Landfill as a Source of Fulvic Acids Polluting
}

\section{Water}

\author{
Tomasz Orliński and Anna M. Anielak \\ Department of Environmental Engineering, Cracow University of Technology, Krakow, 31-155, Poland
}

\begin{abstract}
The FAs (fulvic acids) belong to natural organic contaminants that are commonly found in different environments. In the process of oxidation and disinfection FAs are precursors of toxic substances, which cause a problem in many water treatment plants. In the sewage treatment plants, FAs are not biodegradable and together with purified wastewater and are discharged into surface waters. One of important source of the formation of FAs is the municipal landfill. In this thesis the authors test the amount of soluble fulvic acids present in the leachate of Barycz landfill in Krakow. The extracted FAs were subjected to a detailed analysis for the content of metals and IR spectrum analysis has also been done. Basing on elemental composition the $\mathrm{C} / \mathrm{O}, \mathrm{C} / \mathrm{H}$ and $\mathrm{C} / \mathrm{N}$ ratios have been determined. The obtained data were compared with the characteristics specified in the literature.
\end{abstract}

Key words: Fulvic acids, humic acids, humic substances, landfill, leachate, waste.

\section{Introduction}

The most common practice in the field of solid waste management is their depositing at a waste disposal site where chemical and biological degradation processes take place. As a result of the decomposition of waste, leachates and other products are formed. Current legal solutions regarding municipal landfills, take into account the physicochemical characteristics of leachate but do not assess their toxicity. It is generally known that leachate from the repository generally contains various impurities [1] including: organic substances (biodegradable and non-biodegradable), microorganisms, heavy metals, chlorinated organic and inorganic salts, which are mostly dangerous to the environment and human health. The results of tests carried out on the leachate of eight landfills in France indicate that most metals (or metalloids) are concentrated in the $<30 \mathrm{kDa}$ fraction. While lead, copper and cadmium are associated with larger particles, i.e. fulvic acids forming complexes with them

Corresponding author: Tomasz Orliński, M.Sc.; research fields: environmental engineering, water and wastewater technology.
[2]. In landfills, such waste as: used batteries, fluorescent lights, thermometers, etc. is deposited. As a result of the degradation of organic waste, mercury is transformed into volatile elemental mercury, resulting in the formation of highly toxic methyl mercury [3]. The leachate of waste landfills, as a result of leaching of pollution from the repository and infiltration into the soil, is a source of potential contamination of groundwater and surface waters. Some types of organic leachate substances interact with heavy metals and become their carriers $[4,5]$. Studies have shown that the concentration and composition of the leachate depend on the age, according to which the leachates can be divided into: young, medium and old. The old leachate is characterized by a high content of organic substances with considerable resistance to biodegradation. These are high molecular weight substances, such as HA (humic acid) and FA (fulvic acid). The humic acids of old leachate are characterized by a higher fluorescence intensity [6]. However, young leachates are readily biodegradable. One of the unique features of HS (humic substances) is their heterogeneity in terms of elemental composition, because HS can come from any organic materials, 
including plant and animal remains, microfauna, organic waste, pesticides, etc. FA can form different fractions, differing from each other [7]. Due to this diversity, fulvic acids affect the behavior of some pollutants in the natural environment: on trace metals and their speciation, toxicity and adsorption of hydrophobic impurities [8], the formation of carcinogenic, mutagenic and teratogenic by-products of the oxidation and disinfection process [9]. Research conducted on humic substances originating from peatlands of the forest-tundra zone in the north-east of Russia, showed that their composition depends on: the intensity of cryogenic processes in the active layer, the quality of the humification of precursors (transformation degree of peat material) and biochemical selection of aromatic fragments during humification. HA and FA of peat soils showed a low degree of condensation and a small amount of aromatic fragments [10]. Functional groups of HA, such as: carboxylic, hydroxyl, and especially thiol groups, interact very strongly with mercury. Studies show that in the anaerobic leachate of the landfill, there is a strong interaction between HA and mercury, stronger than in semi-aerobic leachate [3]. Previous practice shows that leachate from landfills is directed to biological municipal sewage treatment plants. The humic substances contained in them are resistant to biodegradation and do not undergo biochemical degradation. HS are partially adsorbed on activated sludge, in the treated wastes they undergo further humification and finally they are discharged with treated wastewater to surface waters. In water treatment plants, in the oxidation and disinfection process, they are precursors of THM (trihalomethanes) and other products of the oxidation and disinfection process [9, 11]. Therefore, research on leachate treatment is widely conducted. Good results are obtained using the photo-Fenton method. Research shows that this method can increase the biodegradability of leachate, as evidenced by the increase in their $\mathrm{BOD}_{5} / \mathrm{COD}$ ratio (from 0.18 to 0.39 ) and the Zahn-Wellens test (Dt $>70 \%$ ) [12]. For the removal of FA, adsorption on: goethite, magnetite, activated carbon with the addition of iron salt, whose cations form a bridge between FA and adsorbent, increasing the efficiency of the process, can be used [13, 14]. Other studies have shown that biosorption of high molecular weight humic substances on activated sludge is possible and should be considered as a preliminary step preceding the breakdown of enzymatic hydrolysis [15]. Research carried out on FA and HA isolated from Suwannee water, consisting of adsorption of given acids on activated sludge, showed the effect of $\mathrm{pH}$, calcium and ionic strength on biosorption. The biosorption of HS was in agreement with the Freundlich isotherm equation and was higher for low $\mathrm{pH}$ values, which can be attributed to the hydrophobic interactions between extracellular active biomass polymers and HS. Similar dependencies were obtained by purifying the effluents in the ANAMMOX reactor, where biosorption of impurities occurred, mainly due to electrostatic interaction and their hydrophobicity. At the same time, we know that HS are the basic organic component of soil [16]. There are also known methods for extracting HS from leachates. For example, in a two-stage reverse osmosis process, it can achieve efficiency $>94 \%$. Therefore, research should be carried out to determine the number and location of humic substances, their elemental composition, the nature of the structure and the content of micro-pollutants, in terms of their use for the enrichment of wastelands and green areas.

\section{Characteristics of Municipal Waste Landfill Barycz in Krakow}

The Barycz municipal waste storage facility is located in the southern part of the city of Krakow, in the Swoszowice district, about $9.5 \mathrm{~km}$ from its center. Since 1974, wastes from the city of Krakow and Wieliczka, are deposited on the site of the Wieliczka Salt Mine. The total area of the facility is 36 hectares and it is divided into three parts corresponding to three 
stages of operation, differing morphologically and technologically. The waste landfill is surrounded by an insulating green belt of a total area of about 16 hectares, which reduces the emission of noise and odors outside the site. Since 1995, Barycz municipal waste management administrator in Krakow is Municipal Waste Treatment Company in Krakow.

In the landfill, processed municipal waste and non-hazardous waste are deposited, in quantities not exceeding $240,000 \mathrm{Mg} /$ year. The waste is deposited in layers, compacted by compactors up to a layer of about $2 \mathrm{~m}$, disinfected with chlorinated lime and insulated with a layer of soil or fine debris, about $0.2 \mathrm{~m}$ thick.

The municipal waste disposal facility in Krakow has an installation for degassing of the remaining waste. Water and leachate are captured through a drainage system. The collected leachate is directed via a sanitary sewage system to the Municipal Waste Water Treatment Plant Płaszow in Krakow.

\section{Material and Methods}

Samples were collected permanently, in the month of January from the reinforced concrete reservoir for leachates with a capacity of $1,600 \mathrm{~m}^{3}$. The tank is located near the active third sector of the landfill. It can be assumed that the collected sample represented leachate collected for at least six months. The total volume of the collected and averaged sample was $20 \mathrm{~L}$.

\subsection{Extraction of FAs}

A sample of leachate was acidified to $\mathrm{pH} \leq 2$ with $\mathrm{HCl}$. After 24 hours, the filtrate was filtered through a medium thickness filter with glass balls $<0.5 \mathrm{~cm}$ in diameter and passed through the ionic bed at a rate of about $1 \mathrm{~L} / \mathrm{hr}$. The volume of leachate directed to the ionic bed was $20 \mathrm{~L}$.

Then $\mathrm{NaOH}$ solution was directed onto the ionite to desorb adsorbed humic acids. Because of the high $\mathrm{NaOH}$ content of the resulting solution, the permeate was directed to the cation exchanger. The resulting leach was concentrated in a vacuum evaporator at a vacuum of 350 bar and a temperature of $85{ }^{\circ} \mathrm{C}$. The leakage was then evaporated on a water bath at $100{ }^{\circ} \mathrm{C}$ to give a dry weight of fulvic acids (Fig. 1). FAs were obtained according to the method accented by the IHSS (International Humic Substances Society).

Analysis of carbon, hydrogen and nitrogen content was done using a chromatographic detection technique (elemental analysis). The analysis used from 5 to $10 \mathrm{mg}$ of sample. The analysis of the remaining elements was done using XRF (X-ray fluorescence). The analysis was carried out in a powder analysis vessel on $4 \mu \mathrm{m}$ thick Proline film. Brune's ED-XRF spectrometer, Bruker's S8 Tiger spectrometer and Thermo's EA Flash element analyzer were used.

The ash design was done by thermogravimetric method using the SDT Q600 thermogravimeter from TA instruments. The heating rate was $10{ }^{\circ} \mathrm{C} / \mathrm{min}$ to $700{ }^{\circ} \mathrm{C}$ in airflow of $100 \mathrm{~mL} / \mathrm{min}$. The analysis used from 5 to $10 \mathrm{mg}$ of sample.

Identification of compound was made using FT-IR with ATR. The spectral range was $65-4,000 \mathrm{~cm}^{-1}$ at 1 $\mathrm{cm}^{-1}$ resolution and 32 scans. The Thermo Nicolet FT-IR iS10 spectrophotometer was used.

\section{Results and Discussion}

Leaks from the Barycz municipal landfill were characterized by dark brown color and unpleasant odor. After filtration and ion exchange, the effluents partially lost coloration, turning the color to light brown. As a result of the processes shown in Fig. 1, $119.75 \mathrm{mg}$ of fulvic acid with $1 \mathrm{~L}$ of leachate were obtained. The extracted FAs formed a clear brown solution with water. Dried FAs were subjected to qualitative analysis. The elemental composition of the obtained FAs is shown in Table 1, the atomic quotient in Table 2, and the micropollutants in Table 3.

The extracted FAs were slightly different in composition compared to the literature data. They contained less hydrogen $4.29 \%$ (according to literature $6.2-9.6 \%$ ) and sulfur $2.78 \%$ (according to literature $1.53-1.86 \%$ ). Comparison with other values in 
literature [17] is presented in Table 1.

Based on the analyzed FAs, $\mathrm{H} / \mathrm{C}, \mathrm{O} / \mathrm{H}, \mathrm{O} / \mathrm{C}$ and $\mathrm{C} / \mathrm{N}$ molar ratios were calculated. $\mathrm{H} / \mathrm{C}$ atomic ratio allows to determine the aromaticity of the acids or the degree of condensation of the aromatic rings [18]. The H/C ratio is 0.93 and is slightly less than the literature data (Table 2). The molar $\mathrm{O} / \mathrm{C}$ ratios coincide with the literature data. Large values were obtained for the $\mathrm{C} / \mathrm{N}$ quotient equals 60.65 , which is due to the low nitrogen content of the FAs molecule.

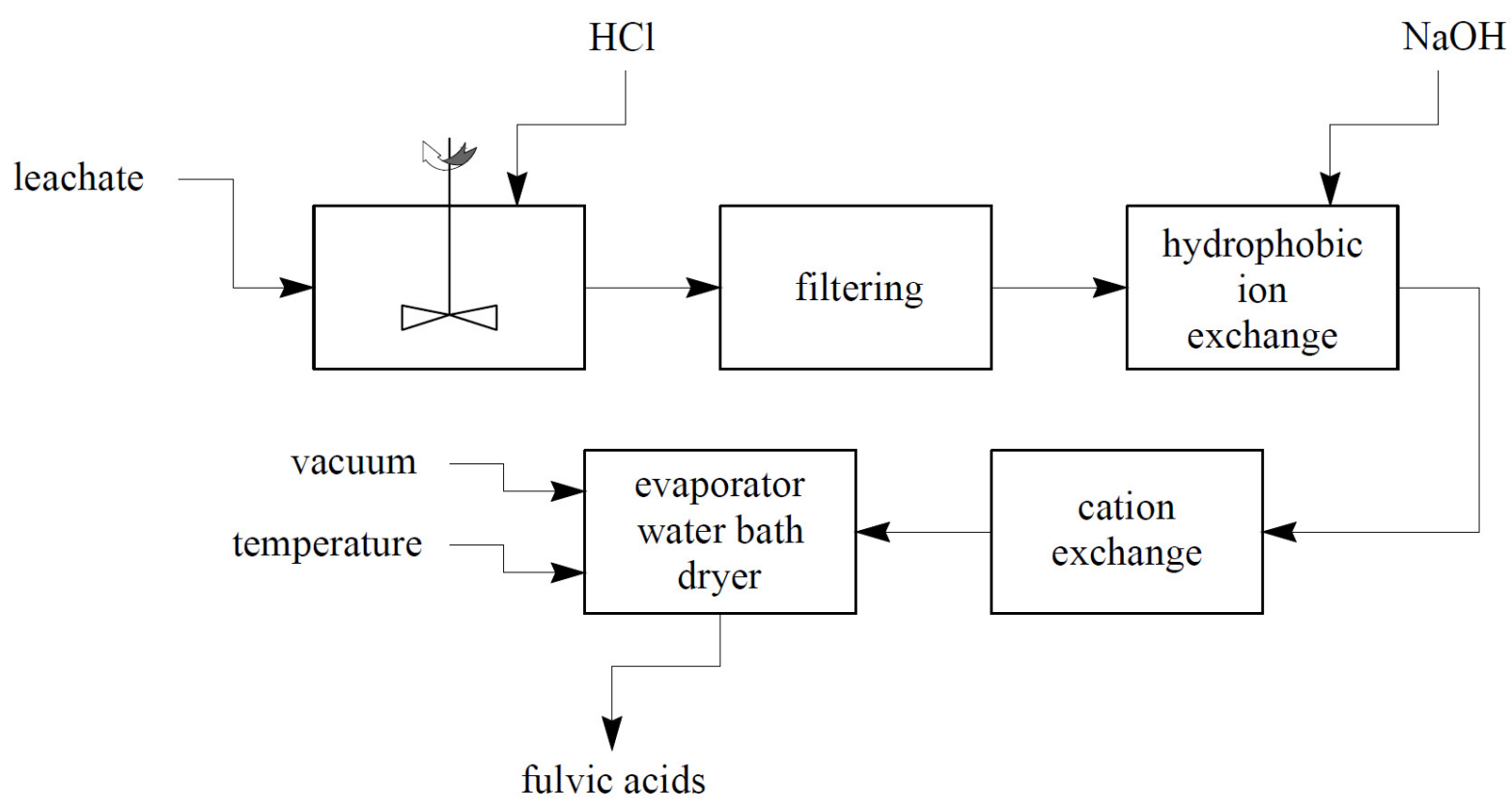

Fig. 1 Diagram of obtaining FAs.

Table 1 Elemental composition of FAs coming from leachate.

\begin{tabular}{lll}
\hline Elemental composition & Content [\%] & $\begin{array}{l}\text { Literature } \\
\text { Content [\%] }\end{array}$ \\
\hline $\mathrm{C}$ & 55.36 & $45.6-55.7$ \\
$\mathrm{H}$ & 4.29 & $6.2-9.6$ \\
$\mathrm{~N}$ & 1.07 & $1.0-12.0$ \\
$\mathrm{~S}$ & 2.78 & $1.53-1.86$ \\
$\mathrm{O}$ & 36.50 & $29.6-50.0$ \\
\hline
\end{tabular}

${ }^{a}$ Based on six different landfills [17].

Table 2 Atomic ratios of the fulvic substances from leachate.

\begin{tabular}{lll}
\hline Atomic ratio & Atomic ratios & \multicolumn{1}{c}{ Literature $^{\mathrm{a}}$} \\
\cline { 2 - 3 } & & Calculated as mole fraction $^{-1.34-2.53}$ \\
$\mathrm{H} / \mathrm{C}$ & 0.93 & - \\
$\mathrm{O} / \mathrm{H}$ & 0.53 & $0.40-0.54$ \\
$\mathrm{O} / \mathrm{C}$ & 0.49 & $4.35-33.33$ \\
$\mathrm{C} / \mathrm{N}$ & 60.65 & \\
\hline
\end{tabular}

${ }^{\mathrm{a}}$ Based on six different landfills [17]. 
Table 3 Micropollutants analysis of FA from leachate of Barycz landfill.

\begin{tabular}{lll}
\hline Element & Symbol & Content [\%] \\
\hline Silicon & $\mathrm{Si}$ & 15.58 \\
Sulfur & $\mathrm{S}$ & 4.92 \\
Sodium & $\mathrm{Na}$ & 1.56 \\
Calcium & $\mathrm{Ca}$ & 0.60 \\
Chlorine & $\mathrm{Cl}$ & 0.42 \\
Phosphorus & $\mathrm{P}$ & 0.29 \\
Potassium & $\mathrm{K}$ & 0.28 \\
Barium & $\mathrm{Ba}$ & 0.14 \\
Iron & $\mathrm{Fe}$ & 0.12 \\
Aluminium & $\mathrm{Al}$ & 0.12 \\
Praseodymium & $\mathrm{Pr}$ & 0.11 \\
Scandium & $\mathrm{Sc}$ & 0.05 \\
Magnesium & $\mathrm{Mg}$ & 0.04 \\
Sickel & $\mathrm{Ni}$ & 0.04 \\
\hline
\end{tabular}

Of the 14 analyzed elements having micropollutants of FAs, the dominant amount was silicon (15.58\%). Much less part showed sulfur (4.92\%) and sodium $(1.56 \%)$. The remaining elements tested constituted a small percentage of the total content of the sample.

According to Gonach et al. [19], the humification process is associated with a decrease in hydrogen content and an increase in oxygen content, but also changes in $\mathrm{O} / \mathrm{H}$ and $\mathrm{O} / \mathrm{C}$ atomic ratios. Reducing oxygen is the result of converting carboxyl and aldehyde groups to hydroxyl groups, resulting in changes in the atomic ratios mentioned above [17]. The author's interpretation seems correct. With increasing humification, the amount of organic carbon increases and the $\mathrm{O} / \mathrm{C}$ ratio decreases. According to Gonach et al. [18], the degree of humification is directly proportional to the value of the $\mathrm{O} / \mathrm{H}$ ratio - the higher the ratio, the higher the degree of humification. What should be explained by the fact is that, due to humification in the molecule, there is a greater loss of hydrogen than oxygen. Therefore, the $\mathrm{O} / \mathrm{H}$ ratio for tested humic acids of 0.53 indicates a high degree of humification. For comparison, the mean soil ratio values are 0.43 [20]. The $\mathrm{O} / \mathrm{C}$ atomic number indicates the carbohydrate content of the organic sample and determines the degree of oxidation. An $\mathrm{O} / \mathrm{C}$ ratio of 0.49 is a proof of a small amount of carboxyl groups and a high carbon content in the test sample, which confirms the high degree of aromaticity of fulvic acids. Żdanow [21] introduced the degree of oxidation of the FAs molecule, determined by the value of $\omega$, from the formula: $\omega=$ $[(2 \mathrm{O}+3 \mathrm{~N})-\mathrm{H}] / \mathrm{C}$ [22]. Calculated on the basis of percentages, the value for analyzed FAs is 2.45 , which indicates a very high degree of oxidation, confirming the high level of humification.

The ratio of carbon to nitrogen determines the direction and intensity of the transformation of organic matter and nitrogen compounds. The calculated $\mathrm{C} / \mathrm{N}$ atomic ratio of equals 60.65 is greater than the quotient of other FAs occurring in surface waters. The high degree of humification and the $\mathrm{C} / \mathrm{N}$ ratio may indicate that there is a large amount of organic material, which is resistant to biological degradation. This value is also the result of the humification of FAs, with which the organic carbon content rises and the nitrogen decreases. Surface waters usually have FAs about low level of humification. Acids with a high degree of humification convert into more hydrophobic fractions that feed on bottom sediments.

The ash content in the analyzed FAs was $27.94 \%$ of total weight, indicating a high level of contamination with inorganic substances (Table 3). The elemental composition of FAs also contains a number of elements, generally considered to be toxic. The reason is the 
negative functional groups found in parts of aliphatic FAs which readily adsorb heavy metals and other substances.

\section{Infrared Spectrum}

Adsorption spectra are used to identify functional groups, substitution types, and double bond configurations because they are characteristics of chemical substances. Analysis of the infrared spectra of the FAs tested is presented in Table 4.

On the obtained spectrogram (Fig. 2), several bands characteristic for FAs are clearly marked. A wide peak $\left(3,194 \mathrm{~cm}^{-1}\right.$ absorption band) was found in the range of about 3,000-3,200 $\mathrm{cm}^{-1}$, which means the stretching of $\mathrm{O}-\mathrm{H}$ bonds of alcohols, phenols and carboxyl groups, and the $\mathrm{N}-\mathrm{H}$ binding vibration of amides and amines

\section{$[17,23]$.}

A clearly marked signal in the band of about 1,703 $\mathrm{cm}-1$ characterizes the presence of $\mathrm{C}=\mathrm{O}$ carbonyl groups in peptides, aldehydes and ketones and is associated with the presence of $\mathrm{C}=\mathrm{O}$ double bonds and $\mathrm{C}=\mathrm{O}$ stretching of carbonyl groups in ketones and quinones. The presence of $\mathrm{C}=\mathrm{O}$ bonds confirms the high maturity of the fulvic acids. The $1,617 \mathrm{~cm}^{-1}$ band indicates the presence of $\mathrm{C}=\mathrm{C}$ bonds in aromatic combinations and the $\mathrm{C}=\mathrm{O}$ bond in quinones. The $1,402 \mathrm{~cm}^{-1}$ band is associated with $\mathrm{O}-\mathrm{H}$ bond deformation, $\mathrm{CH}_{3}$ bending, $\mathrm{C}-\mathrm{O}$ phenolic $\mathrm{OH}$ stretching and $\mathrm{COO}$ carboxylate stretching. It also demonstrates the presence of $\mathrm{C}-\mathrm{H}$ bonds in methyl groups. The highest intensity of the adsorption bands was found in the area of $1,083 \mathrm{~cm}^{-1}$, which proves the

Table 4 Interpretation of IR spectral bands of fulvic substances.

\begin{tabular}{|c|c|}
\hline Wavelenght $\left(\mathrm{cm}^{-1}\right)$ & Interpretation* \\
\hline 3,194 & $\begin{array}{l}\text { O-H vibrations of the hydroxyl groups of phenols, alcohols and carboxyl functions and } \mathrm{N}-\mathrm{H} \text { vibrations from } \\
\text { amides and amines, } \mathrm{NH}_{2} \text { stretch ( } 2 \text { bands) }\end{array}$ \\
\hline 1,703 & $\begin{array}{l}\mathrm{CO} \text { carbonyl groups in peptides, aldehydes and ketones, double bonds of } \mathrm{C}=\mathrm{O}, \mathrm{C}=\mathrm{O} \text { bonding of carbonyl } \\
\text { groups in ketones and quinones }\end{array}$ \\
\hline 1,402 & $\mathrm{O}-\mathrm{H}$ deformation, $\mathrm{CH}_{3}$ bending, $\mathrm{C}-\mathrm{O}$ stretching of phenolic $\mathrm{OH}$, and $\mathrm{COO}$-antisymmetric stretching \\
\hline 1,083 & C-O-C stretching of carbohydrates, S-O stretch, Si-O stretch \\
\hline 950 & Out-of-plane bending of aromatic C-H \\
\hline 792 & $\mathrm{NH}_{2}$ out of plane \\
\hline 670 & S-O bends \\
\hline
\end{tabular}

* Source: Refs. [17, 23, 24].

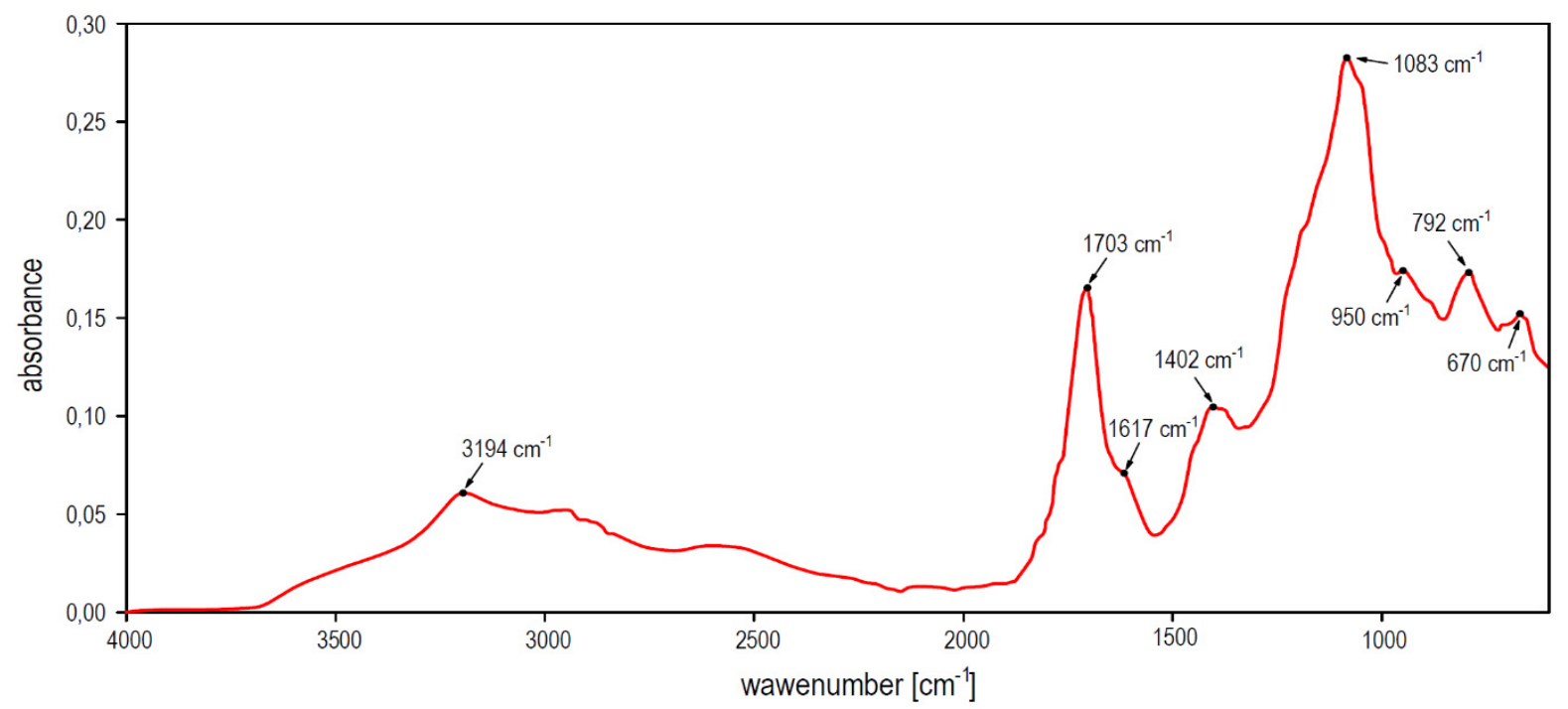

Fig. 2 Infrared spectra of FAs from leachate of Barycz landfills. 
extension of $\mathrm{C}-\mathrm{O}$ bonds derived from $\mathrm{OCH}_{3}, \mathrm{COH}$ and COC groups of organic or mineral-related compounds, and also involves silicate contaminants and S-O bonds. A range of $950 \mathrm{~cm}^{-1}$ confirms the bending vibration of aromatic $\mathrm{C}-\mathrm{H}$ alkene compounds in the FAs tested. Clear peaks were observed at $792 \mathrm{~cm}^{-1}$ and $670 \mathrm{~cm}^{-1}$. The first shows the $\mathrm{NH}_{2}$ plane deformation, while the second one is the flexural bend $\mathrm{S}-\mathrm{O}[3,17,23,24]$.

\section{Conclusions}

(1) The leachate from the Barycz landfill was characterized by the presence of fulvic acids in an amount $119.75 \mathrm{mg} / \mathrm{L}$.

(2) Sample analysis showed significant inorganic contaminats. Dry matter content after roasting was $27.94 \%$. This demonstrates the high chemical activity of the tested acids, which become carriers of toxic micro-contaminants.

(3) $\mathrm{H} / \mathrm{C}, \mathrm{O} / \mathrm{H}, \mathrm{O} / \mathrm{C}$ and $\mathrm{C} / \mathrm{N}$ atomic ratios showed:

- high aromaticity, high acidity and high condensation of aromatic rings;

- very high degree of humification and degree of oxidation of FAs molecules.

(4) Infrared spectra showed a high proportion of aliphatic and aromatic structures in the study of FAs and high maturity of FAs.

\section{References}

[1] Ghosh, P., Thakur, I. S., and Kaushik, A. 2017. "Bioassays for Toxicological Risk Assessment of Landfill Leachate: A Review." Ecotoxicology and Environmental Safety 141: 259-70.

[2] Claret, F., Tournassat, C., Crouzet, C., Gaucher, E. C., Schäfer, T., Braibant, G., and Guyonnet, D. 2011. "Metal Speciation in Landfill Leachates with a Focus on the Influence of Organic Matter." Waste Management 31 (9-10): 2036-45.

[3] Cai, X. L., Hao, Y. X., Liu, G. X., Li, Z. G., and Zhao, Y. C. 2013. "The Effect of Aerobic Conditions on the Complexation Ability between Mercury and Humic Acid from Landfill Leachate and Its Implication for the Environment." Chemosphere 92 (4): 458-63.

[4] Kjeldsen, P., Barlaz, M. A., Rooker, A. P., Baun, A., Ledin, A., and Christensen, T. H. 2002. "Present and
Long-Term Composition of MSW Landfill Leachate: A Review." Critical Reviews in Environmental Science and Technology 32 (4): 297-336.

[5] Zhang, J., Gong, J. L., Zenga, G. M., Ou, X. M., Jiang, Y., Chang, Y. N., Guo, M., Zhang, C., and Liu, H. Y. 2016. "Simultaneous Removal of Humic Acid/Fulvic Acid and Lead from Landfill Leachate Using Magnetic Graphene Oxide." Applied Surface Science 370: 335-50.

[6] Cai, X. L., Liu, G. X., Zhao, X., Hao, Y. X., and Zhao, Y. C. 2012. "Fluorescence Excitation-Emission Matrix Combined with Regional Integration Analysis to Characterize the Composition and Transformation of Humic and Fulvic Acids from Landfill at Different Stabilization Stages." Waste Management 32: 438-47.

[7] Bai, Y., Wu, F., Xing, B., Meng, W., Shi, G., Ma, Y., and Giesy, J. P. 2015. "Isolation and Characterization of Chinese Standard Fulvic Acid Sub-fractions Separated from Forest Soil by Stepwise Elution with Pyrophosphate Buffer." Scientific Reports 5: 8723.

[8] Kang, K. H., Shin, H. S., and Park, H. 2002. "Characterization of Humic Substances Present in Landfill Leachates with Different Landfill Ages and Its Implications." Water Research 36 (16): 4023-32.

[9] Anielak, A. M., Grzegorczuk, M., and Schmidt, R. 2008. "The Products of Oxidation of Fulvic Acids with Sodium Chlorate(I) and Dioxidane." Przemyst Chemiczny 87 (6): 702-6.

[10] Vasilevich, R., Lodygin, E., Beznosikov, V., and Abakumov, E. 2018. "Molecular Composition of Raw Peat and Humic Substances from Permafrost Peat Soils of European Northeast Russia as Climate Change Markers." Science of the Total Environment 615: 1229-38.

[11] Uyguner, C. S., Hellriegel, C., Otto, W., and Larive, C. K. 2004. "Characterization of Humic Substances: Implications for Trihalomethane Formation." Analytical and Bioanalytical Chemistry 378 (6): 1579-86.

[12] Welter, J. B., Soares, E. V., Rotta, E. H., and Seibert, D. 2018. "Bioassays and Zahn-Wellens Test Assessment on Landfill Leachate Treated by Photo-Fenton Process." Journal of Environmental Chemical Engineering 6 (1): 1390-5.

[13] Weng, L., Van Riemsdijk, W. H., Koopal, L. K., and Hiemstra, T. 2006. "Ligand and Charge Distribution (LCD) Model for the Description of Fulvic Acid Adsorption to Goethite." Journal of Colloid and Interface Science 302 (2): 442-57.

[14] Zhou, Y., Zhang, Y., Li, G., and Jiang, T. 2016. "Effects of Metal Cations on the Fulvic Acid (FA) Adsorption onto Natural Iron Oxide in Iron Ore Pelletizing Process." Powder Technology 302: 9-99.

[15] Esparza-Soto, M., and Westerhoff, P. 2003. "Biosorption 
of Humic and Fulvic Acids to Live Activated Sludge Biomass." Water Research 37 (10): 2301-10.

[16] Dinh, Q. T., Li, Z., Tran, T. A. T., Wang, D., and Liang, D. 2017. "Role of Organic Acids on the Bioavailability of Selenium in Soil: A Review." Chemosphere 184: 618-35.

[17] Han, Y. S., Lee, J. Y., Miller, C. J., and Franklin, L. 2009. "Characterization of Humic Substances in Landfill Leachate and Impact on the Hydraulic Conductivity of Geosynthetic Clay Liners." Waste Management \& Research 27 (3): 233-41.

[18] Qi, G., Yue, D., and Nie, Y. 2012. "Characterization of Humic Substances in Bio-treated Municipal Solid Waste Landfill Leachate." Frontiers of Environmental Science \& Engineering 6 (5): 711-6.

[19] Gonach, A. M., El-Halafawi, M. H., and El-Essawi, T. M. 1978. "Some Chemical Characteristics of Humic Acids Isolated from Different Sources." Alexandria Journal of Agricultural Research 26 (3): 747-54.

[20] Smoliński, S., and Spychaj-Fabisiak, E. 2004.
"Characterization of Humic Acids Properties Exudated from the Incubated Soil with an Addition of Plant Material." Annales Universitatis Mariae Curie-Składowska Sectio. E 60 (1): s. 317-324.

[21] Żdanow, J. A. 1965. "Srednjaja stepen okislenija ueleroda i nezamenimost aminokislot." Biochimija 30: 1257-9.

[22] Boguta, P., D’Orazio, V., Sokołowska, Z., and Sensei, N. 2016. "Effects of Selected Chemical and Physicochemical Properties of Humic Acids Frompeat Soils on Their Interaction Mechanismswith Copper Ions at Various pHs." Journal of Geochemical Exploration 168: 119-26.

[23] Huo, S., Xi, B., Yu, H., He, L., Fan, S., and Liu, H. 2008. "Characteristics of Dissolved Organic Matter (DOM) in Leachate with Different Landfill Ages." Journal of Environmental Sciences 20 (4): 492-8.

[24] Zhang, S. Q., Yuan, L., Li, L., Lin, Z. A., Li, Y. T., Hu, S. W., and Zhao, B. Q. 2017. "Characterization of pH-Fractionated Humic Acids Derived from Chinese Weathered Coal." Chemosphere 166: 334-42. 